\title{
ADOBE FLASH AS PLATFORM FOR CREATION OF ONLINE MULTIMEDIA EDUCATIONAL CONTENT
}

\section{Kamil KOPECKÝ}

Abstract: The article describes world's standard for creation of multiplatform multimedia content Adobe Flash with aiming on using in educational process. Article describes elementary features of development environment of Adobe Flash (for example in connection with $3 D$ imaging), introduces examples of multimedia educational objects increasing effectivity of educational process.

Key words: Adobe Flash, multimedia content, Papervision3D, education, MCO, SWF.

\section{ADOBE FLASH JAKO PLATFORMA PRO TVORBU ONLINE MULTIMEDIÁLNÍHO VZDĚLÁVACÍHO OBSAHU}

Resumé: Přrispěvek se zabývá světovým standardem pro tvorbu multiplatformního multimediálního obsahu se zaměrením na využití voblasti vzdělávání. Popisuje základni vlastnosti vývojového prostředí Adobe Flash (např ve vztahu k propojitelnosti s $3 D$ zobrazováním), uvádí př́klady konkrétnich multimediálních vzdělávacích objektů využitelných ke zvýšeni efektivity vzdělávacího procesu.

Klíčová slova: Adobe Flash, multimediální obsah, Papervision3D, vzdělávání, MCO, SWF

\section{Úvod do problematiky}

Adobe Flash představuje jedinečné vývojové prostředí a světový standard pro tvorbu multiplatformního multimediálního obsahu vhodného pro distribuci $\mathrm{v}$ online prostředích (web/v rámci edukace $v$ tzv. LMS či VLE), stejně jako pro vývoj multimediálních aplikací pro offline distribuci (CD-ROMy, DVD). Díky podpoře široké řady grafických, zvukových a animačních formátů umožňuje vytvářet softwarové produkty, které lze považovat za základ multimediálního obsahu distribuovaného na internetu. Flash Player jako standardní přehrávač online multimediálního obsahu má v současnosti (12/2008) dle statistických údajů firmy Adobe nainstalováno $99 \%$ počítačů připojených $\mathrm{k}$ internetu (1). Adobe Flash je tedy nejrozššřenější multimediální formát internetu.

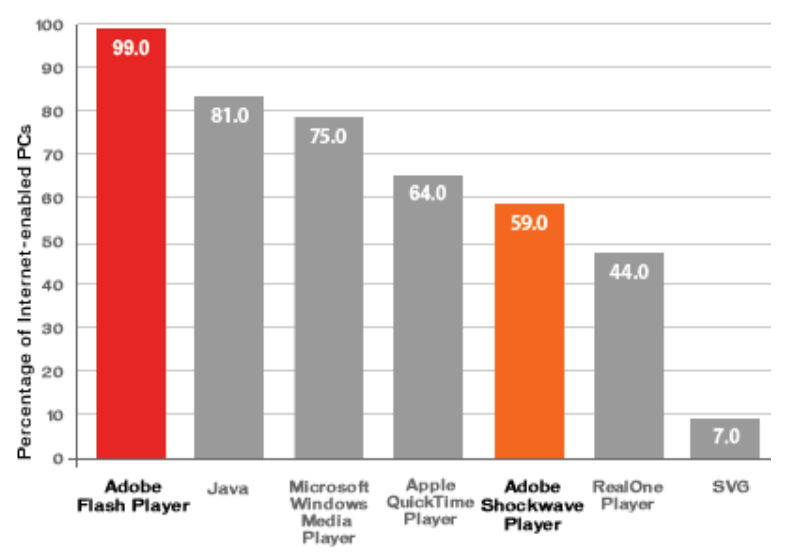

Millward Brown survey, prosinec 2008 (Adobe)
Za povšimnutí stojí také stále větší podpora SWF formátu $\mathrm{v}$ rámci mobilních zařízení smartphonů a pocket pc (či mda), čímž se Flash stává skutečně multiplatformním multimediálním nástrojem.

Technologie Adobe Flash (formát Shockwave) byla a je stále více využívána pro tvorbu multimediálního obsahu určeného pro vzdělávání (tzv. MCO - Multimedia Content Objects), který je prezentován pomocí webu či pouze prostřednictvím desktopových aplikací (např. aplikací využívajících interaktivní tabuli či aplikací přistupujících z desktopu ke vzdáleným službám).

Samotné prostředí Adobe Flash lze rozdělit na dvě základní vývojové platformy - vizuální animační prostředí (nástroje, časová osa, knihovna apod.) a programátorské protředí s podporou objektově orientovaného programování (ActionScript 2/3). To činí Flash prístupný různým typům uživatelů - mohou jej využívat například učitelé, kteří chtějí vytvářet jednoduché animace či interaktivní multimedia, aniž musejí nutně znát programátorské prostředí. Navíc mohou uživatelé od verze 10 (CS4) využívat plnohodnotnou podporu $3 \mathrm{D}$ zobrazování (perpektivní i isometrické s harwarovou akcelerací), inverzní kinematiku a další vizualizační možnosti, známé z o třídy dražších 3D modelovacích a animačních nástrojů (3D Max, Maya, AutoCad). Sám o sobě však Flash umožňuje pouze transformaci 2D objektů do 3D 
prostředí, plnohodnotné 3D zobrazení umožňuje až ve spojení s 3D zobrazovacími knihovnami (např. Papervision3D, Sandy, Away). Důležitá a nezanedbatelná je také možnost propojit Flash s databázovými systémy a umožnit tak práci $\mathrm{s}$ externími daty (napřs. $\mathrm{s}$ podporou XML), možnost využívat pokročilé filtry pro stínování objektů, integrace technologie Adobe Pixel Blender, podpora streamování a pseudostreamování videa (formát FLV či novější $\mathrm{F} 4 \mathrm{~V}$ ), podpora práce $\mathrm{s}$ webkamerou apod. Díky tomu mohou učitelé $\mathrm{v}$ jednom prostředí např. vytvářet pseudostreamované video, simulace $\mathrm{v} 3 \mathrm{D}$ prostředí apod.

\section{Flash a 3D zobrazování}

Skutečným průlomem $\mathrm{v}$ technologii Flash bylo propojení jazyka Actionscript 2/3 s open source knihovnou PaperVision3D (2). Ta totiž umožňuje zobrazit a interaktivně pracovat s různými typy $3 \mathrm{D}$ modelů, exportovaných např́iklad $\mathrm{z}$ již zmiňovaných modelovacích prostředí vyšších řádů - a to včetně textur, osvětlování scény apod. Podporuje totiž formát Collada (3) (Collaborative Design Activity Digital Asset Exchange - soubory *.dae), který je založen na otevřeném jazyce XML (formát Collada byl vytvořen firmou Sony Computer Entertainment původně pro Playstation3, dnes funguje jako open source projekt). Co to tedy znamená? Pomocí Flashe můžete snadno v prostředí internetu zobrazit a ovládat 3D objekty stím, že nemusíte do internetového prohlížeče instalovat žádné př́ídavné moduly. Samotný postup je díky otevřenému kódu a množství dostupných tutoriálů poměrně jednoduchý, výsledek je pak velmi efektní. V rámci vzdělávání se tak otevírá široké pole využitelnosti nezávisle na operačním systému či instalovaným pluginům. Pro potřeby vzdělávání se pak otevírá možnost integrovat do výuky 3D virtuální interaktivní učební pomůcky, které umožní účinně podpořit efektivitu vzdělávání. Odpovídá tedy didaktickým požadavkům na názornost a aktivizaci studujících.

\section{Flash a multimediální vzdělávací objekty}

Adobe Flash poskytuje jedinečné možnosti pro vzdělávání podporované informačními a komunikačními technologiemi - zejména $\mathrm{v}$ rámci e-learningového vzdělávání (např̀. na vysokých školách), frontální výuky (např̀ při práci s interaktivní tabulí na všech typech škol) či jako podpora domácí přípravy žáků. Multimediální objekty lze sdílet také prostřednictvím e-learningového standardu SCORM (pomocí tzv. SCO - Shareable Content Objects) - snadno je přenášet a importovat do vzdělávacích systémů, které standardizovanou výměnu dat umožňují. V praxi bude tedy stejný obsah fungovat $\mathrm{v}$ různých vzdělávacích prostředích.

Při tvorbě multimediálních objektů je nutné respektovat základní principy tzv. kognitivního modelu aplikace multimedií (4):

1. Vždy je lepší vysvětlovat učivo mluveným slovem a obrazem, než pouze obrazem.

2. Vždy je lepší studentům prezentovat učivo $\mathrm{s}$ podporou multimedií ve stejném čase $-\mathrm{tj}$. v průběhu výkladu, než jako doplňkový materiál. Např́klad při výkladu fungování spalovacího modelu je výhodné pracovat $\mathrm{s}$ funkčním multimediálním (či reálným) modelem, než jen se statickou slovní informací. Je tedy vhodné využívat simulace.

3. Pokud využíváme $\mathrm{k}$ výkladu multimediální objekty s textovou informací, vždy ji čtěme. Neomezujme se jen na „text na plátně“!

4. Jednotlivé principy jsou významnější pro „slabší studenty“ než studenty nadané a aktivní, také jsou vhodnější pro více posluchačủ (např́ílad pro přednášky $\mathrm{v}$ aule apod.) než pro malé publikum.

5. Při multimediálním výkladu využívejme spíše méně slov (rozumějme text) než více. Studenti se lépe učí $z$ jasně strukturovaného nerozvitého textu. Nepoužívejme dlouhých souvětí!

Je tedy zřejmé, že MCO objekty jsou ideálním interaktivním spojením verbálních a neverbálních složek s respektováním didaktických zásad.

\section{Ukázky multimediálních vzdělávacích objektů}

Pro demonstraci fungování MCO objektů přikládáme ukázky, které se využívají ve výuce různých předmětů (ZŠ, SŠ, VŠ).

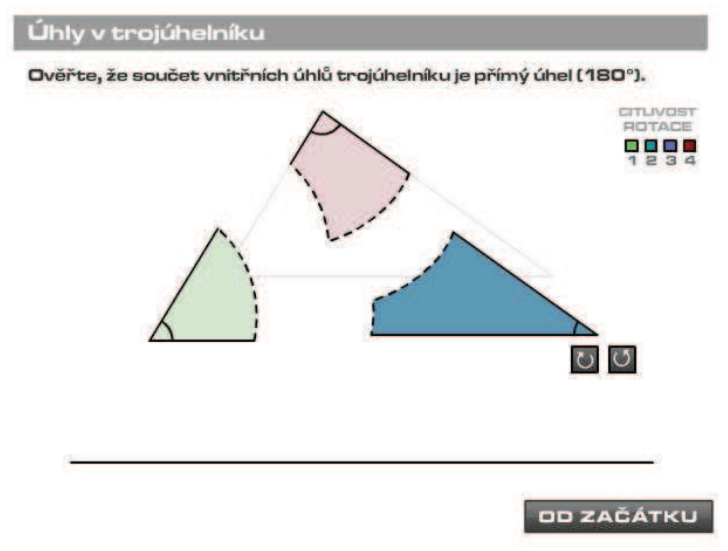




\section{MCO: Úhly v trojúhelníku}

Úkolem interaktivního multimediálního objektu je naučit žáky či studenty, že součet vnitřních úhlů trojúhelníku odpovídá př́ímému úhlu $\left(180^{\circ}\right)$. S jednotlivými částmi trojúhelníku lze manipulovat, posouvat je v prostoru objektu a otáčet s nimi. Úkolem je přiložit je spodní čáru tak, aby tvořily přímý úhel.

Ukázka z projektu: Zvýšení úrovně vzdělávání $v$ matematice ve studijním oboru Učitelství pro 1. stupeň základní školy (ESF OP RLZ)
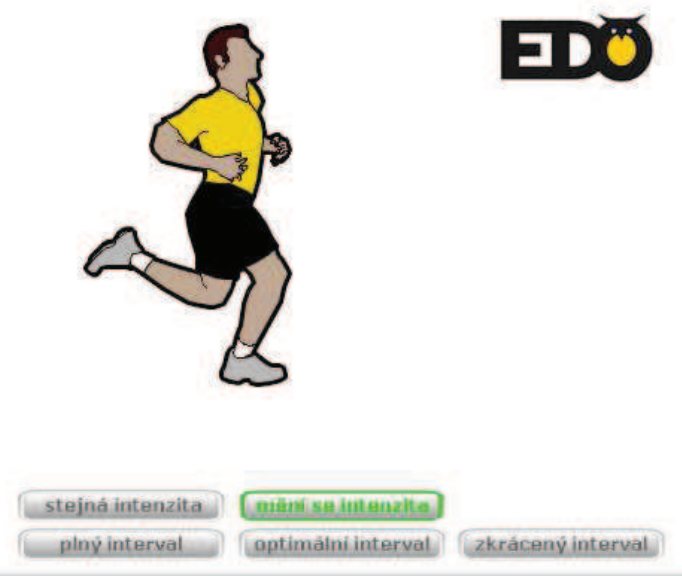

\section{MCO: Kruhový trénink}

Tento multimediální objekt učí studenty trenérství rozpoznávat různé varianty tréninku. Při přepínání jednotlivých stylů tréninku animovaná postava mění svoje tempo a zobrazuje, jak jednotlivé typy tréninku probíhají (plný interval/optimální interval/zkrácený interval při různé intenzitě).

Ukázka z projektu:EDO - Tvorba e-learningových distančních opor (ESF OR RLZ)

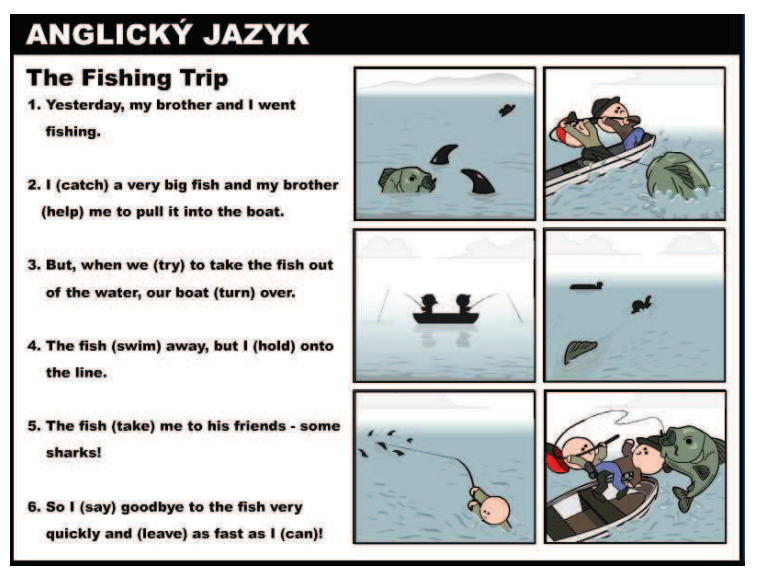

\section{MCO: The Fishing Trip}

Multimediální zpracování cvičení The Fishing Trip, jehož úkolem je poskládat správně př́běh $\mathrm{v}$ angličtině, přičemž máme $\mathrm{k}$ dispozici anglické věty s přeházenými doprovodnými obrázky. Obrázky vyjadřující obsah jednotlivých vět lze přesouvat a postupně pak vytvořit logicky navazující príběh.

Ukázka z projektu ZŠ Štěpánov na podporu tvorby didaktických pomuicek pro interaktivní tabuli.

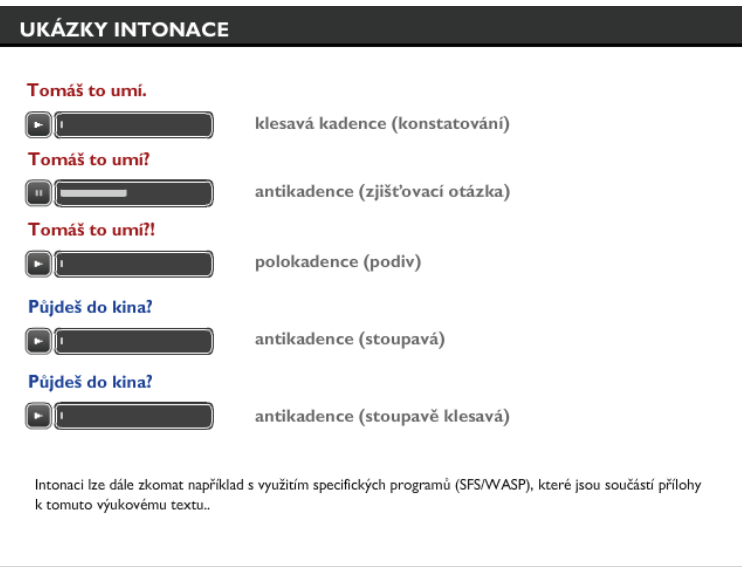

\section{MCO: Ukázky intonace}

Multimedium, které učí studenty českého jazyka rozpoznávat jednotlivé typy české intonace v rámci předmětu Fonetika a fonologie. Student si může přehrát formálně stejné věty s různou intonací a porovnat tak jednotlivé typy (ukázka pracuje se zvukovým záznamem).

Ukázka z e-learningové opory předmětu Úvod do fonetiky a fonologie, Pedagogická fakulta UP.

\section{Závěr}

Aby byla integrace multimediálních vzdělávacích objektů do vzdělávacího systému úspěšná, je nutné, aby se učitelé naučili s těmito multimédii pracovat a aby si osvojili alespoň základy jejich tvorby (5). Jak již bylo řečeno výše, Adobe Flash je navržen tak, aby s ním mohli pracovat i uživatelé bez programátorských zkušeností - tedy i učitelé, kteří mají zájem o využívání ICT ve výuce. Proto lze všem učitelům jen doporučit využít možností vzdělávacích agentur a vysokých či středních škol, které kurzy Adobe Flash nabízejí (více např. na http://odborict.upol.cz/).

\section{Literatura, zdroje}

(1) Millward Brown. Methodology for Adobe plug-in technology study. Adobe, 2008. URL: $<$ http://www.adobe.com/products/player_census/ methodology/> 
(2) Google. Papervision 3D

URL: < http://code.google.com/p/papervision3d/>

(3) Khronos Group. Collada

URL: $<$ https://collada.org/>

(4) MORENO, R. MAYER, R. Cognitive principles of multimedia learning: The role of modality and contiguity. Journal of Educational Psychology, $1999 . \quad$ p. 358-368. (5) LISALOVÁ, J. Využití multimedií ve vzdělávání učitelů. Distanční vzdělávání v České republice - současnost a budoucnost. Praha: Centrum pro studium vysokého školství, 2006.
URL: $<\underline{\text { http://www.csvs.cz/konference/ }}$

NCDiV2006_sbornik/Lisalova.pdf>

Mgr. Kamil Kopecký, Ph.D.

Katedra českého jazyka a literatury

Pedagogická fakulta Univerzity Palackého v

Olomouci

Žižkovo nám. 5, 77140 Olomouc

E-mail: kopeckyk@seznam.cz

Tel: +420 777146808 